\title{
Implementation of Ecoliteracy and Ecorepreneurship to Grow Entrepreneurial Interest of Science Education Students
}

\author{
Noer Af'idah, Lina Arifah Fitriyah, Oktaffi Arinna Manasikana \\ Science Education Department, Hasyim Asy'ari University, Jl. Irian Jaya No.55, Cukir, \\ Jombang, 61471, Indonesia \\ Corresponding email: noerafidah1985@gmail.com
}

\section{Article History}

Received: November 2021

Accepted: December 2021

Published: December 2021

Key Words

Ecoliteracy;

Ecopreneurship;

Entrepreneurial interest

How to cite this article?

\begin{abstract}
This study aimed to foster entrepreneurial interest in Science Education students at Hasyim Asy'ari University through the implementation of ecoliteracy and ecopreneurship in PKLH courses. This research is a type of descriptive research through a qualitative approach wich is carried out as an effort to provide insight and experience to students to reuse waste into quality products and high selling value. This research was conducted during the COVID-19 pandemic through an online system with two stages; first education about the environment (Ecoliteracy) and the second stage in the form of project assignments to manufacture environmental-based entrepreneurial products with waste as the main raw material. The results of the assignment can be used as entrepreneurial product innovations so that students are more creative in producing a product, as well as support one of the government programs to create a healthy and zero waste environment. From this research, it is known that ecoliteracy and ecopreneurship implementation activities can increase students' knowledge about environment; this can be seen from the average pre-test score of 72 to 80 in the post-test and an increase in the percentage of completeness from $73 \%$ to $100 \%$. Likewise, student interest in entrepreneurship increased, it was showed from the average score of pre-test and post-test 76 to 88 . From this activity, student creativity was quite good with an average value 73 , this can be seen from the variety of ecopreneurship products produced both from the types of basic materials and products.
\end{abstract}

Afidah, N., Fitriyah, L., \& Manasikana, O. (2021). Implementation of Ecoliteracy and Ecorepreneurship to Grow Entrepreneurial Interest of Science Education Students. Lensa: Jurnal Kependidikan Fisika, 9(2), 113-123. doi:https://doi.org/10.33394/j-1kf.v9i2.4443

\section{INTRODUCTION}

Education is both a system influenced and influencing one another system; for instance, government of a country and a growth of future society. There are many impacts of the productive society growth for the future; one of the impacts is tight level of competition because high growth society which is not balance with the job availability. Based on this condition, university is one of educational institution is required to produce suitable graduate to the need of work in order to create "link and match" condition (Anih, 2015).

The high number of productive age population growth results in high demand for jobs that can absorb the productive age workers. In the world of employment, the problem of the need for employment occupies is the highest position. This is because the number of entrepreneurs is much smaller than the number of workers who need work. According to Hasan, recently, in Indonesia there are only around 400,000 entrepreneurs or $0.18 \%$ of the total productive age population. This amount certainly cannot balance or accommodate all the work needs of the productive age population. To overcome this 
condition, it is necessary to have an ability to create a new business opportunity (Hasan, 2011).

In a country, entrepreneurs need at least $2 \%$ of the total population so that the country can develop and be able to compete with other countries (Hasan, 2011). According to this, the number of Indonesian entrepreneurs is far from $2 \%$. To increase the number of entrepreneurs in Indonesia as an effort to prosper the nation as well as to help overcome problems due to the high rate of population growth, entrepreneurship education is needed. Entrepreneurship is the ability to create something new and different through creative thinking and acting innovatively in creating opportunities.

One part of entrepreneurship has enormous potential and has not yet been fully developed is ecopreneurship. Ecopreneurship or what we are usually familiar with the term environment-based entrepreneurship is linguistically derived from the words eco and preneur. Eco is short for ecological which can be interpreted as a scientific discipline that studies the interactions between living things and their environment. Preneur comes from the word entrepreneurship, which is the human ability to design One part of entrepreneurship has enormous potential and has not yet been fully developed is ecopreneurship. Ecopreneurship or what we are usually familiar with the term environment-based entrepreneurship is linguistically derived from the words eco and preneur. Eco is short for ecological which can be interpreted as a scientific discipline that studies the interactions between living things and their environment. Preneur comes from the word entrepreneurship, which is the human ability to design something new, innovative, and creative as an effort to create an opportunity for success (Alma, 2010 in Yanti, 2015). So it can be concluded that ecopreneurship is an innovative effort or activity to create an environmentally friendly product that can generate financial benefits by taking advantage of opportunities that available around the environment. Ecopreneurship products utilize natural resources around them that have not been processed optimally (can be in the form of waste/garbage or other natural resources), making ecopreneurship an attractive alternative to entrepreneurial activities from an economic point of view. The raw materials used are cheap and environmentally friendly.

As agents of change, students who will hold the leadership relay in the future must play an active role in being a pioneer in the formation of a strong national economy. Therefore, it is time to change the paradigm of thinking among students. That is from a narrow mindset of looking for work after graduating from college to becoming a job creator based on the creation of small and medium enterprises, so that the Indonesian people can become the host in their own country. This requires knowledge, positive mental attitude, and entrepreneurial skills that have been initiated since college.

Students who are expected to become entrepreneurs in the future need to understand and realize the importance of protecting the environment so that environmental problems that are still encountered today can prevented as early as possible. Changes in human attitudes and behavior in favor of the environment cannot be realized in a short time, but it takes a hard process and collaboration from various parties for that students need a learning model about environmental care so that students have a high awareness of the environment. This concern for the environment will affect the entrepreneurial spirit of students in the future (Arafat at al, 2013).

In a study entitled "Ecopreneurship Utilizing Local Resources to Increase Entrepreneurial Interest and Environmental Literacy" showed that students' entrepreneurial interest in the initial and final tests remained in the high category with an average increase of 4 points with the overall environmental literacy score of students in the category medium and student responses to ecopreneurship-based biology learning in a good category (Suryaningsih, 2020). Research conducted by Mufidah et al. (2021) show 
that the application of ecoliteracy and ecopreneurship in project-based learning can foster creativity, students' entrepreneurial spirit and literacy toward the environment.

From the description above, this research aims to increase knowledge about environmental literacy, foster interest in entrepreneurship, and increase the creativity of science education students by the implementation of ecoliteracy and ecopreneurship through the PKLH (Population and Environmental Education) course.

\section{METODE}

This research is descriptive qualitative. It is implemented in $\mathrm{PKLH}$ (Population and Environmental Education) through online learning. It focused on providing experience in a form of assignment project making a entrepreneurial product made from waste to the students of science education department 2018, consisted of 15 people. Students were expected to gain knowledge in the form of environmental literacy, to acquire skills, to increase creativity in designing and making entrepreneurial products that are environmentally friendly.

In this research, researcher used pre-test and post-test, entrepreneurial interest questionnaires and product creativity assessment sheets as instrument. The tests were pretest and post-test about ecoliteracy material. The pre-test and post-test question sheets were used to determine the level of students' understanding of environmental literacy before and after the learning process. The pre-test and post-test sheets include 20 multiple choice questions and 5 essay. While the entrepreneurship interest questionnaire was used to find out how the students' interest and interest in doing entrepreneurship activities was after they designed and completed the task of making ecopreneurship product works. The entrepreneurship interest questionnaire consists of 15 statements. The indicators of interest in entrepreneurship refer to Kusumajanto (2015) which consist of: 1) entrepreneurial desire; 2) interest in establishing a business; 3) pleasure in entrepreneurial activities; 4) attention to entrepreneurial activities; 5) willingness to work hard; 6) willingness to develop business; and 7) willingness to take risks. The product creativity assessment sheet is used to assess the student's ability to create a new product, the level of product originality, product attractiveness, and product benefits for the community. The level of creativity is closely related to a person's ability to become an entrepreneur (Hendro, 2011). Creativity and entrepreneurial skills were closely related as like two sides of a coin. One side of entrepreneurial skills is academic knowledge and achievement, while on the other side creativity is the ability to manage, empower, and utilize academic knowledge in overcoming problems, difficulties, and challenges faced.

Analysis of ecoliteracy test score was carried out descriptively by calculating pre-test and post-test scores. Ecoliteracy ability is considered complete if it gets a score of 70. The calculation of the entrepreneurship interest questionnaire according to the Likert scale based on the score of the answer choices Strongly Agree (SS) $=4$, and Disagree (ST) $=1$. The criteria for interest in entrepreneurship are determined based on Table 1.

Table 1. Enterpreneurship interest criteria

\begin{tabular}{lc}
\hline Interval & Enterpreneurship Interest Criteria \\
\hline $20 \%-36 \%$ & Very Low \\
$37 \%-53 \%$ & Low \\
$54 \%-70 \%$ & Neutral \\
$71 \%-87 \%$ & High \\
$88 \%-100 \%$ & Very High \\
\hline
\end{tabular}

Adapted from Rahayu (2011)

This research was conducted using a project-based learning method for four weeks. The first week begun with learning about environmental literacy (ecoliteracy), it was an 
online learning activities by providing education about the environment, human activities that can damage the environment, waste, types of waste, negative impacts of waste on human health, how to manage waste, and some examples of products resulting from waste processing. In the second week, students were asked to design entrepreneurial products from waste. Students were given a freedom to determine the type of waste raw materials, manufacturing methods, and product designs that they would make. The third week was the finalization stage of ecopreneurship products that have been designed by students, while the lecturers monitored and provided input on the products made. Then in the fourth week, the lecturers conducted an assessment and held an appreciation event by asking students to present their ecopreneurship products through online. From this activity, students were expected to have an understanding of the concept of environmental literacy (ecoliteracy), as well as the skills to create environmental-based entrepreneurial products. With these activities, students' interest in entrepreneurship can be increased.

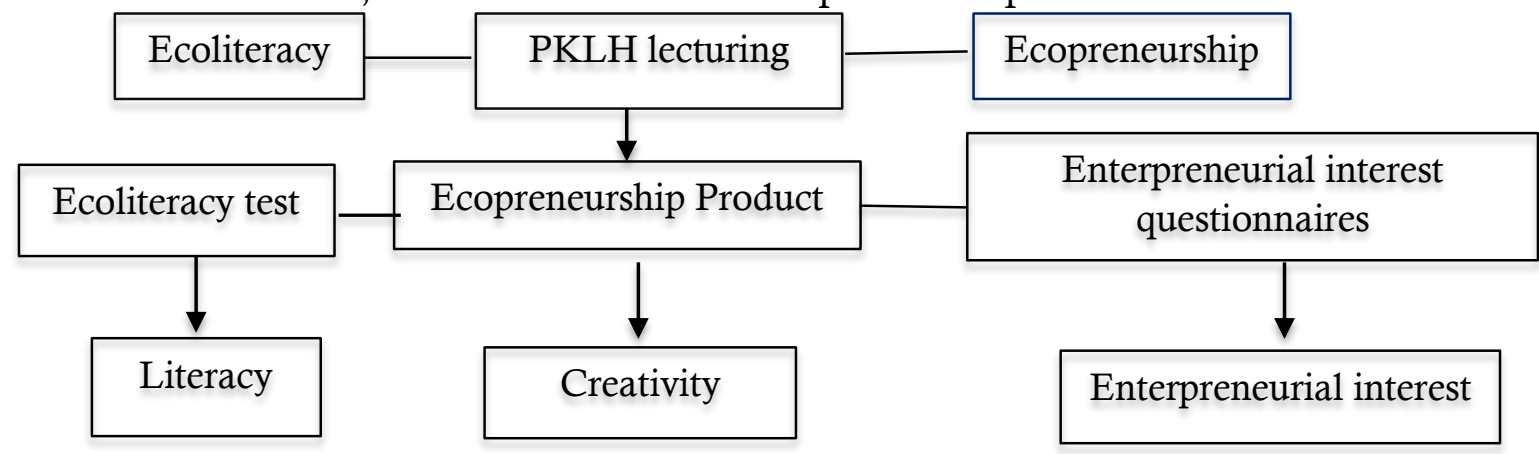

Figure 1. Research steps

\section{RESULTS AND DISCUSSION}

Ecoliteracy through PKLH (Population and Environmental Education) Ecopreneurship Course

Table 2. Ecoliteracy Pre-test and post-test score of Science Education students

\begin{tabular}{|c|c|c|c|c|c|}
\hline \multirow{2}{*}{ No. } & \multirow{2}{*}{ Student's Name } & \multicolumn{4}{|c|}{ Score of Literacy Test } \\
\hline & & Pre-Test & Description & Post-Test & Description \\
\hline 1. & SL & 70 & complete & 78 & complete \\
\hline 2. & EN & 75 & complete & 80 & complete \\
\hline 3. & DA & 76 & complete & 85 & complete \\
\hline 4. & $\mathrm{AF}$ & 65 & incomplete & 73 & complete \\
\hline 5. & $\mathrm{MNF}$ & 78 & complete & 80 & complete \\
\hline 6. & SU & 72 & complete & 78 & complete \\
\hline 7. & SF & 71 & complete & 83 & complete \\
\hline 8. & DSH & 60 & incomplete & 76 & complete \\
\hline 9. & ASA & 67 & incomplete & 78 & complete \\
\hline 10. & QU & 78 & complete & 80 & complete \\
\hline 11. & $\mathrm{RN}$ & 78 & complete & 83 & complete \\
\hline 12. & IFM & 80 & complete & 95 & complete \\
\hline 13. & SAN & 70 & complete & 78 & complete \\
\hline 14. & SZ & 71 & complete & 80 & complete \\
\hline 15. & QA & 67 & incomplete & 78 & complete \\
\hline & Average Score & 72 & & 80 & \\
\hline & $\%$ of completeness & 27 & & 100 & \\
\hline & The Highest Score & 80 & & 95 & \\
\hline & The Lowest Score & 60 & & 73 & \\
\hline Ler & nal Kependidikan $F$ & D & & & 116 \\
\hline
\end{tabular}


Ecoliteracy is carried out with the aim of providing information and forming concepts about the environment, human activities that can damage the environment, waste, waste management, human efforts to preserve the environment, and examples of waste processing products. To find out the level of students' understanding of environmental literacy, tests were conducted before and after lecture activities. The pretest and post-test scores for science education students' eco-literacy can be seen in Table 2 above.

From Table 1, it can be seen that students' knowledge about environmental literacy after receiving education about the environment while applying the knowledge gained by making eco-preneurship products has increased. This can be seen from the mean value of 72 on the pre-test to 80 on the post-test score. There is an increase in the percentage of completeness from $73 \%$ to $100 \%$. This shows that students' knowledge can be increased by actively involving them through direct practical activities. Eco-literacy activities were carried out with the aim that the level of awareness and awareness of students to preserve the environment could be increased. Involving students directly through project-based lecture activities was expected to be more motivated and impactful when compared to learning in theory only.

\section{Students' entrepreneurial Interest through Ecoprenourship Implementation}

In the Big Indonesian Dictionary, interest is defined as a high tendency of the heart towards something. Interest in entrepreneurship was the tendency of the heart to be interested in forming a business which then regulates, organizes, faces risks and improves the business that had been formed (Mahesa \& Rahardja, 2012). Someone who had an interest in entrepreneurship, then he would have a high interest in creating something new, something unique, innovative, and different by taking advantage of opportunities that existed around the environment and made into a product that could generate financial benefits. Fatimah \& Purdianto (2020) through their research results showed an influence between entrepreneurship education and interest in entrepreneurship. Someone who took entrepreneurship education would understand the benefits of being an entrepreneur and would be increasingly interested in becoming an entrepreneur.

Table 3. Entrepreneurial interest of Science Education Students

\begin{tabular}{cccc}
\hline No. & Student's Name & Early Interest & Final Interest \\
\hline 1. & SL & 75 & 83 \\
\hline 2. & EN & 74 & 79 \\
\hline 3. & DA & 76 & 80 \\
\hline 4. & AF & 80 & 83 \\
\hline 5. & MNF & 85 & 91 \\
\hline 6. & SU & 80 & 98 \\
\hline 7. & SF & 78 & 96 \\
\hline 8. & DSH & 70 & 86 \\
\hline 9. & ASA & 72 & 94 \\
\hline 10. & QU & 78 & 92 \\
\hline 11. & RN & 70 & 78 \\
\hline 12. & IFM & 80 & 98 \\
\hline 13. & SAN & 75 & 93 \\
\hline 14. & SZ & 71 & 82 \\
\hline 15. & QA & 73 & 80 \\
\hline & Average score & $\mathbf{7 6}$ & $\mathbf{8 8}$
\end{tabular}


Interest in entrepreneurship can be identified by providing a research instrument in the form of a questionnaire on entrepreneurship interest. This questionnaire was given to students before and after this research activity was carried out. The purpose of this questionnaire activity was to determine the level of change in students' interest in entrepreneurship before and after the lecture activities are carried out. Lecture activities are carried out in two stages, namely education about environmental literacy (eco-literacy) and project assignments for making ecopreneurship products. The recapitulation of the entrepreneurship interest of science education students was presented in Table 3 above. Based on the data in Table 3, the entrepreneurship interest of students of the Science Education Department before the implementation of ecopreneurship was actually quite high, with an average score of 76. However, after the implementation of this ecopreneurship, students' interest in entrepreneurship could be increased to 88 . Based on the average score on previous interest, it could be seen that most of the Science Education students were already interested in becoming an entrepreneur, then the interest in entrepreneurship was higher after the implementation of ecopreneurship.

\section{Eco-friendly Ecopreneurship Products}

PKLH (Population and Environmental Education) is one of the compulsory subjects for Unhasy Science Education students. One of the objectives of this course is students understand about the environment and care more about the environment. So far, entrepreneurship courses and PKLH courses stand alone, it means that the material in PKLH is not integrated with entrepreneurship and vice versa. Even though there are a lot of products from PKLH lecture assignments that are made from waste that have economic value that can be sold. Through the implementation of ecopreneurship in this PKLH course, students were expected to increase their creativity, concern for the environment, interest in entrepreneurship and their entrepreneurial skills.

Ecopreneurship products can be considered as an alternative solution in overcoming environmental problems. It is because many ecopreneurship products are made by reusing and recycling waste that is no longer useful to become an item of economic value. Ecopreneurship products are environmentally friendly products, because the ecopreneurship concept is one of the material processing and production concepts that strives to always be environmentally friendly.

Project assignments in the form of environmentally friendly entrepreneurial products were made with waste raw materials. In a point of view, there are two groups of ecopreneurship products produced by students; ecopreneurship products made from organic waste and ecopreneurship products made from inorganic waste. The following are some ecopreneurship products created by science education students, which can be seen in Table 4.

Table 4. Ecopreneur products created by science education students Unhasy

\begin{tabular}{|l|l|l|}
\hline No. & Name of Products & Figure \\
\hline 1. & Sweets made from orange skin & \\
& & \\
\hline 2. & Art paper made from vegetable trash & \\
& & \\
\hline
\end{tabular}




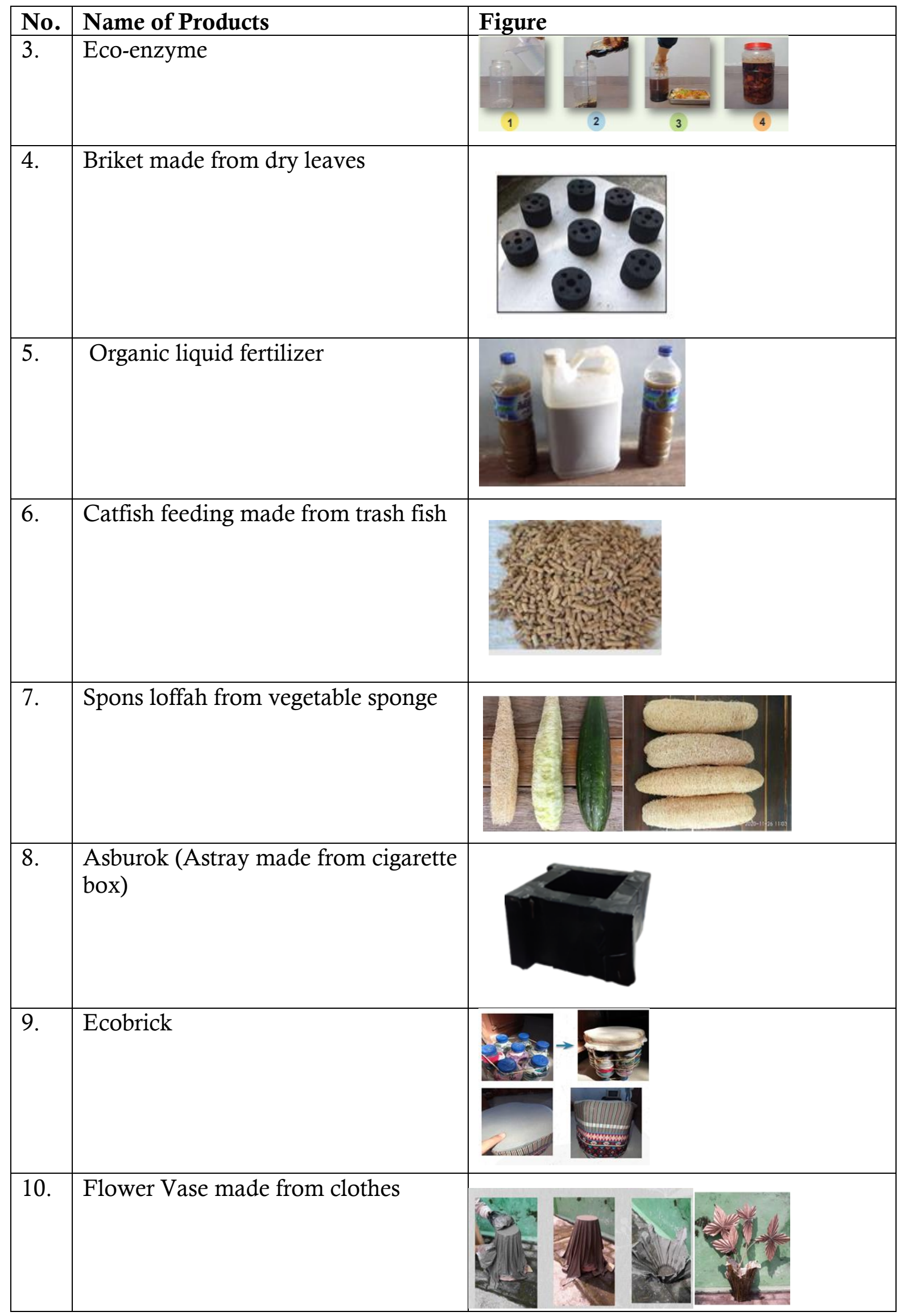




\begin{tabular}{|l|l|l|}
\hline No. & Name of Products & Figure \\
\hline 11. & $\begin{array}{l}\text { Flower accessories made from recycle } \\
\text { mask }\end{array}$ & $\begin{array}{l}\text { Phone holder made from recycled } \\
\text { pipe }\end{array}$ \\
\hline 12. & \begin{tabular}{l} 
Pencil case from reused bottle \\
\hline 14.
\end{tabular} & Tissue case made from recycle box \\
\hline 15. & $\begin{array}{l}\text { Pencil case made from ice cream } \\
\text { sticks }\end{array}$ \\
\hline
\end{tabular}

Based on the Table 4 above, it can be seen that most students prefer to make ecopreneurship products based on inorganic waste. This is because there are several possibilities, firstly, inorganic waste is more easily decomposed by microorganisms so that organic waste rots faster. If it is used as a basic material for making ecopreneurship products and the manufacturing process is not appropriate, then the resulting product is damaged quickly and is not durable. The second possibility is the consideration of students preferring to use inorganic waste as a basic material, because organic waste is a type of waste that is very difficult to decompose by microorganisms. So that in large quantities this type of waste is very disturbing environmental sustainability if not handled properly.

\section{The Creativity of Science Education Students After Implementing Ecopreneurship}

Creativity was a person's ability to create an idea by making new combinations based on existing information and data (Munandar, 2009). According to Putra et al. (2016) creativity was the result of a person's creative thinking activities to find or develop a new idea or idea that is original (original), aesthetically, constructively related. A creative person has the ability to create a new idea or concept about something. The ability to think creatively was to think to find, synthesize, build, to decide and produce new ideas (Purwaningrum, 2016). In entrepreneurship activities, an entrepreneur was required to have high creativity to support the success of the business carried out. So the level of creativity was directly proportional to the ecopreneurship products produced. So a good ecopreneurship product was a representation of a person's ability to develop his creativity. 
Assessment of student ecopreneurship product creativity includes several aspects, those are: Preparation, it was an assessment of the student's ability to design and design the product to be made; Product manufacturing techniques, it was student assessments when conducting the process of selecting raw materials and product manufacturing techniques appropriately; Product evaluation, it includes overall ecopreneurship product assessment, product uniqueness, product neatness, product attractiveness, and aspects of product.

The average score of ecopreneurship product creativity of the science education students is presented below.

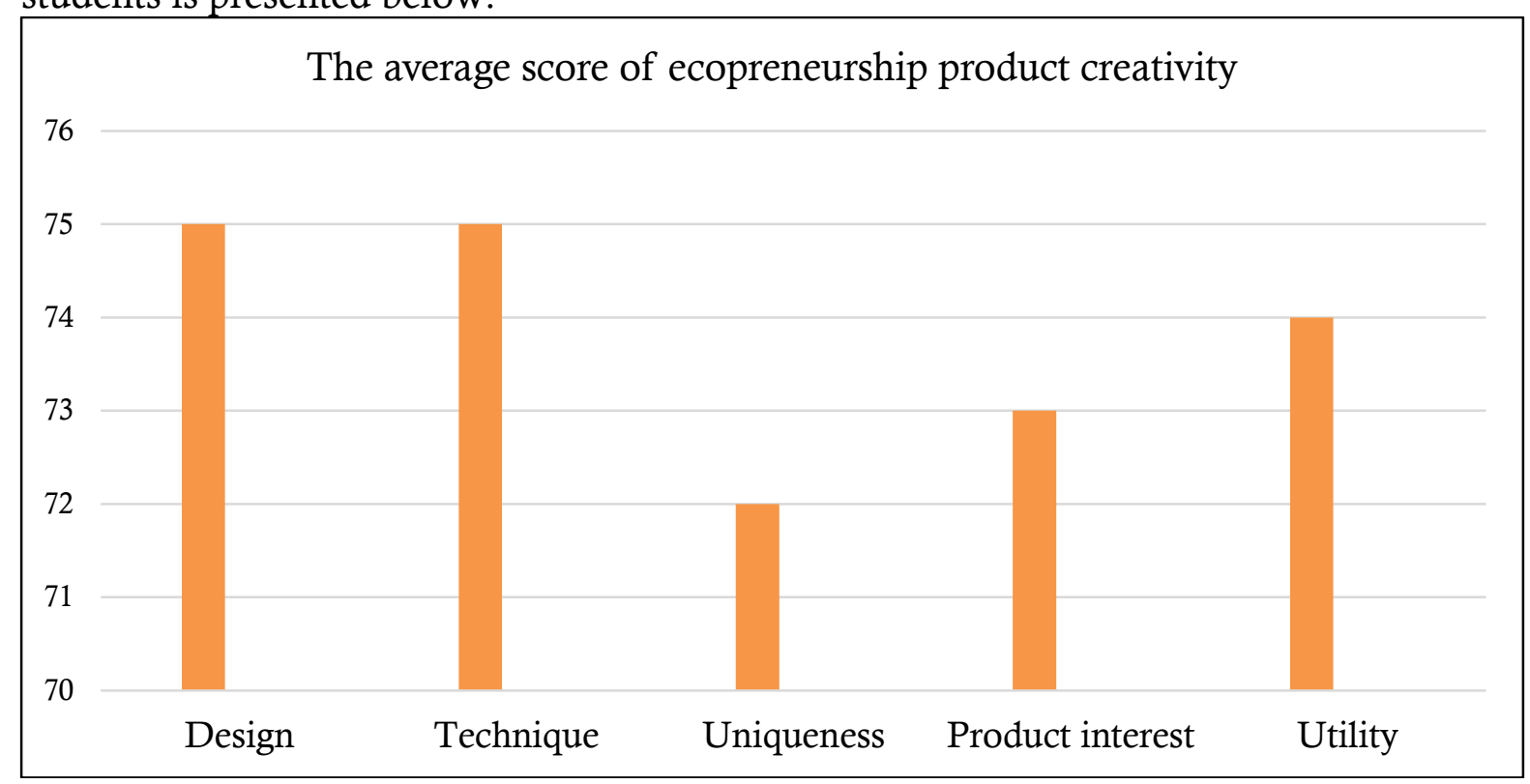

Figure 2. Graphic of the average score ecopreneurship product creativity

Based on Figure 2, It can be seen that the creativity level of Unhasy Science Education students is quite good, with an average value of 73 . The lowest value is for aspects of product uniqueness and product attractiveness. Most of the ecopreneurship products produced have shortcomings in these two aspects. Students focused more on product design and manufacturing techniques. The pandemic situation has caused the limitations of students to get materials around their house; so many students made ecopreneurship products with available materials. Students do not think about the uniqueness and attractiveness of the products they made.

\section{CONCLUSSION}

Based on the finding and discussion above, then it can be concluded that the implementation of ecoliteracy and ecopreneurship in PKLH courses can increase the understanding of Unhasy Science Education students about eco-literacy, this can be seen from the pre-test mean score of 72 to 80 at the post-test and an increase in the percentage of completeness from $73 \%$ to $100 \%$. The entrepreneurship interest of science education students has increased after the implementation of ecopreneurship from the average interest score of 76 to 88. The creativity of the students of the Science Education Study Program after the implementation of ecopreneurship is quite good, namely getting an average value of 73 . 


\section{RECOMMENTATION}

Based on the research conducted, that this research should not stop at the stage of producing only products, but also need to add knowledge about how to package and market ecopreneurship products that are appropriate, unique, and attractive in order to get satisfactory results. In addition an encourage of entrepreneurship skills can be done through other courses, so that students can increase their interest and ability to be entrepreneurship. This research was conducted during the covid-19 pandemic, so it could not carry out ecopreneurship product exhibition

\section{ACKNOWLEDGMENT}

Thanks for LPPM UNHASY as the funder of this research.

\section{REFERENCES}

Anih, E., (2015). Ecopreneurship Education Berbasis Prakarya Dalam Kurikulum 2013. Didaktik : Jurnal Pendidikan Guru Sekolah Dasar, 1(1), 113-121.

Arafat, M.Y., Suherman, \& Buchdadi A.D., (2013). Studi Eco-enterpreneurship dalam Meningkatkan Sumber Daya Manusia Yang Berdaya Saing. Research Report Jakarta State University of Jakarta.

Fatimah, S. E., \& Purdianto, A. (2020). Factors Affecting Entrepreneurial Interest Among Students in Higher Education. Advances in Economics, Business and Management Research, In International Conference on Accounting, Management and Entrepreneurship (pp.145-147). Cirebon, Indonesia: Department Management Faculty of Economy Universitas Swadaya Gunung Jati.

Hasan. (2011). Kondisi Dan Fenomena Wirausaha Di Indonesia Studi Dengan Data Sakerti 2007. In International Conference and Call For Papers "Towards Excellent Small Business". Yogyakarta, Indonesia: Muhammadiyah University of Yogyakarta.

Hendro. (2011). Dasar-dasar Kewirausahaan. Jakarta: Erlangga.

Kusumajanto, D. D. (2015). The role of entrepreneurship education and self efficacy inshiping student interest in doing entrepreneurship. European Journal of Business and Management, 7 (28), 153-158.

Mahesa, A. D., \& Rahardja, E. (2012). Analisis Faktor-Faktor Motivasi yang Mempengaruhi Minat Berwirausaha. Diponegoro Journal of Management, 1(1), 130-137. http://www.ejournals1.undip.ac.id/index.php/djom/article/view/787

Mufidah, Z. R., Iswara, P.D., Hermanto, F. Y., (2021). Developing Elementary School Students' Ecoliteracy and Ecopreneurship Through Project-Based Thematic Learning (PjBL). At-Thullab: Jurnal Pendidikan Guru Madrasah Ibdtidaiyah. 5(1), 75-88.

Muthmainnah, (2014). Pengaruh Pelaksanaan OJT (On The Job Training) dan Peran Orang Tua Terhadap Minat Berwirausaha Pada Kelas XII Kompetensi Keahlian Akutansi di SMK Negeri 2 Semarang Tahun Ajaran 2013-2014. Economic Education Analysis Journal. 2(3), Hal 32-38.

Rahayu, E. P. (2011). Pembuatan Tempe sebagai Sumber Belajar Sub Materi Bioteknologi untuk Menarik Minat Berwirausaha Siswa SMA Negeri 1 Tunjungan Blora. Thesis. Semarang State University.

Subandono, A. (2007). Pengaruh Pembelajaran Life Skill Diklat Kewirausahaan Terhadap Minat Berwirausaha Pada Siswa SMK N 1 Semarang. Thesis, State University of Semarang.. 
Suryaningsih. Y., \& Aripin. I., (2020). Ecopreneurship Memanfaatkan Sumber Daya Lokal Untuk Meningkatkan Minat Wirausaha dan Literasi Lingkungan, Pedagogi Hayati Journal. 4(2). 63-70.

Suryawan, P. (2006). Penyimpangan Tumbuh Kembang Anak. Jakarta: Gramedia Pustaka Utama.

Yanti, J. S. (2019). Membuka Usaha Dengan Ecopreneurship. Retrieved from https://osf.io/preprints/inarxiv/hk7yu/. 